\title{
PENGARUH LINGKUNGAN KERJA, MOTIVASI DAN KOMPETENSI TERHADAP KINERJA PEGAWAI PADA LINGKUP BADAN KESATUAN BANGSA DAN POLITIK PROVINSI SULAWESI SELATAN
}

\author{
The Effect of The Work Environment, Motivation and Competency on the Employee Performance in \\ The National Unity and Politics Agency of South Sulawesi Province
}

\author{
Andi Wahyudi Amini Ishak ${ }^{1}$, Andi Rayid Pananrangi ${ }^{2}$ Nurkaidah $^{2}$ \\ ${ }^{1}$ Badan Kesatuan Bangsa dan Politik Provinsi Sulawesi Selatan \\ ${ }^{2}$ Program Studi Ilmu Administrasi Negara Program Pascasarjana Universitas Bosowa
}

Email: a.wahyudiaminiishak@yahoo.com

Diterima: 26 Januari 2020

Dipublikasikan: 05 Juni 2020

\begin{abstract}
ABSTRAK
Penelitian ini bertujuan untuk mengkaji, menganalisis dan menginterpretasi serta melihat fenomena yang ada dan apa yang akan diperlukan terkait dengan efektivitas kebijakan dan strategis dalam memberdayakan pegawai melalui pengamatan atau analisis guna mendapatkan temuan-temuan dalam mengembangkan potensi yang dimiliki oleh setiap pegawai dengan tetap mengacu kepada pendekatan konsep manajemen sumber daya manusia dan perilaku organisasi yang mengarah kepada peningkatan pegawai secara keseluruhan. Variabel dalam penelitian ini adalah lingkungan Kerja $\left(\mathrm{X}_{1}\right)$, Motivasi $\left(\mathrm{X}_{2}\right)$, Kompetensi $\left(\mathrm{X}_{3}\right)$ dan Kinerja $(\mathrm{Y})$ yang diukur dengan skala Likert. Populasinya adalah pegawai Badan Kesbangpol Provinsi Sulawesi Selatan yang berjumlah 60 orang. Penelitian ini menggunakan sampel jenuh. Teknik pengumpulan data yang digunakan adalah angket dan dokumentasi. Teknik analisis data yang digunakan adalah analisis keabsahan data dan analisis statistik data dengan menggunakan program SPSS 20.0 for windows. Hasil penelitian ini menunjukkan bahwa Lingkungan Kerja, Motivasi dan Kompetensi, parsial maupun simultan berpengaruh signifikan terhadap Kinerja pegawai pada Badan Kesbangpol Provinsi Sulawesi Selatan. Motivasi memberikan pengaruh dominan terhadap Kinerja pegawai pada Badan Kesbangpol Provinsi Sulawesi Selatan dibandingkan dengan variabel Lingkungan Kerja dan Motivasi. Jadi dapat ditarik kesimpulan bahwa hipotesis diterima.
\end{abstract}

Kata Kunci : Lingkungan Kerja, Motivasi, Kompetensi, Kinerja Pegawai, Kesbanpol, Sulawesi Selatan

\begin{abstract}
This study aims to examine, analyze, interprete and observe the existing phenomenon and what will be needed related to the effectiveness of policies and strategies in empowering employees through observation or analysis in order to figure out how to develop the potential possessed by the employees while still referring to management concept of human resources and organizational behavior that lead to the overall employee improvement. The variables in this study are the Work Environment $\left(X_{1}\right)$, Motivation $\left(X_{2}\right)$, Competence $\left(X_{3}\right)$ and Performance $(Y)$ which are measured using Likert scale. The population of this study are the employees of the National Unity and Politics Agency of South Sulawesi Province, totaling 60 people. This research uses saturated samples. Data collection techniques used were questionnaires and documentation. The data analysis technique used is data validity analysis and statistical data analysis using the SPSS 20.0 for windows program. The results of this study indicate that the Work Environment, Motivation and Competence, partially and simultaneously, have a significant effect on employee performance at the National Unity and Politics Agency of South Sulawesi Province. Motivation has a dominant influence on employee performance in the National Unity and Politics Agency of South Sulawesi Province compared to the Work Environment and Motivation variables. So it can be concluded that the hypothesis is accepted.
\end{abstract}

Keywords: Work Environment, Motivation, Competence and Performance

\section{PENDAHULUAN}

Organisasi publik mengalami perubahan mengikuti perkembangan zaman, perubahan pada lingkungan dan tuntutan situasi dan kondisi menuntut adanya fleksibilitas terhadap perubahan. Dibutuhkan pengembangan SDM dalam organisasi publik agar terwujud aktivitas yang di tunjukan untuk mengubah perilaku publik. Sehubungan dengan fenomena yang bergejolak dalam internal badan kesbangpol Provinsi Sulawesi selatan saat ini adalah adanya keluhan pegawai tentang kompensasi yang diterima belum mencukupi kebutuhan sehingga harus memanfaatkan sebagai waktur kerja kantor untuk mencari penghasilan tambahan. Fenomena ini tentu mempengaruhi perhatian apar pegawai terhadap penyelesaian tugas yang diberikan.

Organisasi publik menghadapi perubahan lingkungan, serta tuntutan pada situasi dan kondisi yang menuntut adanya fleksibilitas terhadap perubahan tersebut. Fleksibilitas organisasi publik sesuai yang dibutuhkan oleh organisasi dan mampu bekerja dengan orientasi kepada publik. Organisasi yang fleksibel perlu didukung oleh sistem pengembangan Sumber Daya Manusia yang komprehensif, yang mampu merespon 
berbagai tantangan yang di hadapi, sehingga organisasi publik mampu bergerak secara cepat, tanggap, efektif, dan efisien sesuai dengan tuntutan publik.

Oleh karena itu, di butuhkan pengembangan Sumber Daya Manusia dalam organisasi publik agar terwujud dalam aktivitas-aktivitas yang di tunjukan untuk mengubah prilaku organisasi publik yang memiliki dua sasaran yang akan dicapai, yaitu tujuan manusia di dalam organisasi dan tujuan organisasi itu sendiri, dimana keduanya tersebut harus di capai secara seimbang. Setiap organisasi mempunyai tujuan tertentu menurut bidang usahanya masig-masing namun secara pokok sumber daya manusia menunjukan suatu upaya secara disengaja dengan tujuan mengubah prilaku pegawai organisasi publik atau paling tidak meningkatkan kemampuan organisasi publik untuk berubah. Selain itu, juga berperan dalam upaya meningkatkan kesejahteraan masyarakat yang menyangkut aspek kehidupan baik yang fisik maupun non fisik serta menciptakan kemudahankemudahan dalam memberikan pelayanan kepada masyarakat.

Upaya meningkatkan kesejahteraan masyarakat yang menyangkut aspek kehidupan baik yang fisik maupun non fisik serta menciptakan kemudahan-kemudahan dalam memberikan pelayanan kepada masyarakat. Sehubungan dengan kewenangan pemerintah daerah dalam UU No.9 Tahun 2015 Setelah UU No.32 tahun 2004, terdapat dua Undang Undang lain yang membahas pemerintahan daerah, yaitu UU No.12 tahun 2008 dan UU No.23 tahun 2014.

Pemerintah yang memiliki personal dengan potensi kerja yang tinggi ditunjukkan oleh aktifitas kerja dengan memperlihatkan kemampuan seseorang, hal ini tercermin pada peningkatan kinerja yang ditandai pada tingkat penyelesaian untuk meningkatkan ketrampilan pegawai dalam megembang pekerjaan tertentu sesuai dengan pekerjaan yang di emban oleh pegawai untuk memberikan secara keseluruhan sehingga produktifitas kerja merupakan rasio antara output dan input yang dinyatakan atas basis faktor aktifitas secara keseluruhan. Kinerja seorang pegawai dapat diketahui dari hasil suatu pekerjaan yang dapat ditunjukkan dengan derajat kemampuan seseorang dalam menyelesaikan suatu pekerjaan.

Kinerja seorang pegawai dapat diketahui dari hasil suatu pekerjaan yang dapat ditunjukkan dengan derajat kemampuan seseorang dalam menyelesaikan suatu pekerjaan. Tingkat keberhasilan aparatur dalam mengembang tugasnya disebut dengan istilah level of performance atau level kinerja. Organisasi publik menggunakan penelitian kinerja aparatur sebagai salah satu bagian dari kepentingan administratif dan pengembangan dimasa akan datang. Secara administratif, organisasi dapat dijadikan penilaian kinerja sebagai acuan dalam membuat keputusan yang berhubungan dengan konsidi kerja pegawai, termasuk pada promosi untuk tingkatan karir, pemecatan, serta penghargaan atau penggajian.
Badan Kesbangpol Provinsi Sulawesi Selatan sebagai unsur pelaksana tugas-tugas pemerintah, dituntun agar profesional memberikan kesempatan bagi pegawai untuk meningkatkan pengetahuan dan kemampuan yang dimiliki pegawai termasuk meningkatkan perkembangan pribadinya semua pegawai yang ada dalam Provinsi Sulawesi Selatan dan meningkatkan kondisi kerja serta pelayanan kepada masyarakat. Pengukuran kinerja dapat dilakukan dengan mengunakan sistem rating yang relevan. Rating tersebut harus mudah digunakan sesuai dengan apa yang akan diukur, serta mencerminkan hal-hal yang memang menentukan kinerja. Menurut Werther dan David 2008 dalam Pariansa (2017) menyatakan bahwa pengukuran kinerja juga berarti membandingkan antara standar yang telah ditetapkan dengan kinerja yang dihasilkan.

Keberhasilan manajemen organisasi publik, sedikit banyaknya ditentukan oleh keberhasilan pimpinan organisasi publik dalam menumbuhkan komitmen organisasional aparaturnya. Seberapa jauh komitmen organisasional aparatur terhadap organisasi publik akan sangat menentukan pencapaian tujuan organisasi. Nur et al., (2020) bahwa komitmen organisasional aparatur sangatlah penting, karena aparatur yang memiliki komitmen kuat terhadap organisasi publik akan menampilkan kinerja terbaiknya serta produktif dalam mengembang pekerjaan yang dibebankan oleh organisasi publik. Bahkan, dewasa ini organisasi publik mensyaratkan komitmen organisasional merupakan salah satu syarat mutlak dalam memegang jabatan manajerial tertentu.

Motivasi merupakan kegiatan yang mengakibatkan, menyalurkan, dan memelihara perilaku manusia. Motivasi ini menjadi subjek penting bagi manager agar memahami orang-orang yang berperilaku tertentu agar dapat mempengaruhi orang lain bekerja sesuai dengan tujuan organisasi. Motivasi dapat merupakan kekuatan pendorong yang bisa mewujudkan suatu perilaku guna mencapai kepuasan dirinya. Dalam pelaksanaan tugas, pegawai memerlukan motivasi sehingga selalu ada pengembangan ke arah yang lebih maju dan profesional, jadi tidak sekadar sebuah rutinitas. Oleh karena itu, motivasi diduga kuat memberikan pengaruh pada kinerja pegawai pada lingkup Badan Kesbangpol Politik Provinsi Sulawesi Selatan. Selain faktor lingkungan kerja dan motivasi seperti yang telah diuraikan sebelumnya, kompetensi juga merupakan salah satu hal yang berpengaruh terhadap kinerja pegawai.

Kompetensi menjelaskan apa yang dilakukan oleh pegawai di tempat kerja pada berbagai tingkatan dan memperinci standar masing-masing tingkatan, mengidentifikasi karakteristik pengetahuan dan keterampilan yang diperlukan individual yang memungkinkan menjalankan tugas dan tanggung jawab secara efektif sehingga mencapai standar kualitas profesional dalam bekerja dan menghasilkan kinerja yang baik (Wibowo, 2009). Kompetensi pegawai dapat tercapai 
dengan cara memberikan pelatihan kepada pegawai yang sesuai dengan kebutuhan pekerjaan dan tujuan organisasi.

Badan Kesbangpol Provinsi Sulawesi Selatan memiliki pegawai dengan kompetensi yang tidak saling mendukung antara pendidikan yang dimiliki, pengalaman kerja dan pelatihan. Contoh jabatan sebagai pengelola keuangan kompetensi yang dipersyaratkan pendidikan D3 Manajemen/Akuntansi, tetapi dijabat oleh seseorang dari jurusan lain. Menurut Romberg dalam Gatot (2014) seorang pegawai memiliki kompetensi yang tinggi apabila pegawai tersebut memiliki pengalaman kerja, latar belakang pendidikan, keahlian/pengetahuan, keterampilan. Pengalaman kerja dapat 30 meningkatkan kinerja karena seorang karyawan dapat menempatkan diri secara tepat kondisi, berani mengambil risiko, mampu menghadapi tantangan dengan penuh tanggung jawab serta mampu berkomunikasi dengan baik terhadap berbagai pihak untuk tetap menjaga produktivitas, kinerja dan menghasilkan individu yang kompeten dalam bidangnya (Sutrisno, 2009).

Penelitian ini bertujuan untuk mengkaji, menganalisis dan menginterpretasi serta melihat fenomena yang ada dan apa yang akan diperlukan terkait dengan efektivitas kebijakan dan strategis dalam memberdayakan pegawai melalui pengamatan atau analisis guna mendapatkan temuan-temuan dalam mengembangkan potensi yang dimiliki oleh setiap pegawai dengan tetap mengacu kepada pendekatan konsep manajemen sumber daya manusia dan perilaku organisasi yang mengarah kepada peningkatan pegawai secara keseluruhan

\section{METODE PENELITIAN}

\section{Jenis Penelitian}

Penelitian ini bersifat deduktif, dimana untuk menjawab rumusan masalah dengan konsep atau teori sehingga dapat dirumuskan hipotesis yang selanjutnya diuji melalui pengumpulan data dilapangan. data yang telah dikumpul selanjutnya dianalisis secara kuantitatif dengan menggunakan normatif deskripsi atau inferensial sehingga dapat disimpulkan hipotesis yang dirumuskan terbukti atau tidak (Sugiyono, 2017).

\section{Lokasi Penelitian}

Berlokasi pada Badan Kesbangpol Provinsi Sulawesi Selatan di Jalan Jenderal Urip Sumaharjo No 269 Kota Makassar

\section{Populasi dan Sampel}

Populasi dari penelitian ini adalah seluruh pegawai Badan Kesbangpol Provinsi Sulawesi Selatan yang berjumlah 60 orang. Penelitian ini disebut penelitian populasi karena seluruh anggota populasi sebanyak 60 orang dijadikan sampel penelitian.

\section{Instrumen Penelitian}

Instrumen pada penelitian ini berupa koesioner, dimana terdapat tiga variabel yaitu lingkungan kerja, motivasi dan kompetensi terhadap kinerja pegawai. Adapun kisi-kisi instrumen ini bertujuan agar penyusunan instrumen lebih sistematis sehingga mudah dikontrol dan dikoreksi.

Teknik pengumpulan data yang digunakan dalam penelitian ini adalah Observasi dan kuesioner

\section{Variabel Penelitian}

Berdasarkan pokok permasalahan dan hipotesis yang diajukan, variabel-variabel dalam analisis ini dapat diidentifikasi, jadi kalau penelitiakan memilih variabel penelitian, baik yang memiliki orang obyek, maupun bidang kegiatan dan keilmuan tertentu, maka variabel yang tidak ada variasinya bukan dikatakan sebagai variabel.

\section{Jenis dan Sumber Data}

Jenis data yang peneliti gunakan dalam penelitian ini adalah data kuantitatif yaitu metode penelitian berlandaskan pada filsafat positif, digunakan untuk meneliti pada populasi atau sampel tertentu, pegumpulan data menggunakan instrument penelitian, analisis data bersifat kuantitatif dengan tujuan menguji hipotesis sumber data menggunakan data primer dan sekunder yaitu data primer adalah sumber data langsung di lokasi penelitian Badan Kesbangpol untuk memperoleh informasi mendalam tentang hal yang berkaitan dengan pengaruh lingkungan kerja aparatur melalui lingkungan kinerja, motivasi dan kompensasi sedangkan data sekunder adalah data yang tidak langsung memberikan data kepada peneliti, data diperoleh dengan mengunakan studi formatif yang dilakukan terhadap banyak buku, diperoleh dari internet yang berhubungan dengan penelitian (Sugiyono, 2017).

\section{HASIL DAN PEMBAHASAN}

\section{Pengaruh Lingkungan Kerja (X1) terhadap Kinerja(Y)}

Data penelitian dengan perhitungan menggunakan program SPSS22.0 for windows diperoleh nilai signifikan $0,027<\alpha=0,05$ menunjukkan bahwa Lingkungan Kerja berpengaruh positif signifikan terhadap Kinerja pada Lingkup Badan Kesatuan Bangsa dan Politik Propinsi Sulawesi Selatan. Hasil analisis dapat diketahui bahwa Lingkungan Kerja berpengaruh positif dan signifikan terhadap Kinerja pada Lingkup Badan Kesatuan Bangsa dan Politik Propinsi Sulawesi Selatan. Pengaruh Lingkungan Kerja Terhadap Kinerja Berdasarkan hasil analisis yang telah dilakukan maka hipotesis ketiga $\mathrm{H} 3$ ada pengaruh positif dan signifikan lingkungan kerja terhadap kinerja kinerja pegawai Badan Kesatuan Bangsa dan Politik Sulawesi Selatan Hasil penelitian ini sama dengan penelitian yang dilakukan oleh Puspita (2011) dan Subowo (2005) bahwa lingkungan kerja berpengaruh secara positif dan signifikan terhadap kinerja. Untuk meningkatkan kinerja yang efektif dan efisien, pegawai perlu memahami kondisi lingkungan kerjanya begitu pula dengan pimpinan organisasi. Implikasi hasil penelitian ini adalah untuk meningkatkan kinerja Badan Kesatuan Bangsa dan Politik perlu diperhatikan faktor-faktor tujuan yang hendak dicapai, paham tugas pokok, mengetahui cara menggalang kesepakatan dengan mitra kerja, 
mengetahui cara sosialisasi dan mampu melakukan kreatifitas serta inovasi kerja serta penciptaan lingkungan kerja yang nyaman dan tetap pegawai dapat memahami kondisi lingkungan kerja yang merupakan tempat mereka memberikan pegawai Badan Kesatuan Bangsa dan Politik. Temuan peneliti. Pengaruh lingkungan kerja sangat kondusif karna keberadaan kantor di jalan poros dan letak strategis cukup mudah di jangkau cukup berpengaruh dalam peningkatan kinerja pegawai.

Pengaruh Motivasi (X2) terhadap Kinerja(Y)

Data penelitian dengan perhitungan menggunakan program SPSS22.0 for windows diperoleh nilai signifikan $0,013<\alpha=0,05$ menunjukkan bahwa Motivasi berpengaruh terhadap Kinerja pada Lingkup Badan Kesatuan Bangsadan Politik Propinsi Sulawesi Selatan. Berdasarkan hasil analisis dapat diketahui bahwa Motivasi berpengaruh positif dan signifikan terhadap Kinerja pada Lingkup Badan Kesatuan Bangsadan Politik Propinsi Sulawesi Selatan.

Pengaruh motivasi terhadap kinerja berdasarkan hasil analisis terdapat pengaruh positif dan signifikan terhadap kinerja pegawai Badan Kesatuan Bangsa dan Politik Sulawesi Selatan. Hasil penelitian ini sama dengan penelitian yang dilakukan oleh Cahyono (2005); Amat (2001); Arlini (2010) bahwa motivasi berpengaruh secara positif dan signifikan terhadap kinerja. Implikasi dari hasil penelitian ini adalah motivasi yang tinggi mampu meningkatkan kinerja pegawai Badan Kesatuan Bangsa dan Politik Sulawesi Selatan. Motivasi merupakan suatu kekuatan potensial yang ada di dalam diri seorang manusia, yang dapat dikembangkannya sendiri atau dikembangkan oleh sejumlah kekuatan luar, dalam meningkatkan motivasi kerja pegawai perlu ditumbuhkan melalui pemenuhan kebutuhan dalam diri semua pegawai mulai dari yang paling dasar sampai pada tingkatan tertinggi yaitu kebutuhan fisiologis, kebutuhan memperoleh rasa aman, kebutuhan sosial, kebutuhan memperoleh harga diri, dan kebutuhan aktualisasi diri (Gibson, 2006). Motivasi mempunyai peran yang amat penting dalam mendukung peningkatan kinerja pegawai Badan Kesatuan Bangsa dan Politik Sulawesi Selatan. Temuan peneliti motivasi selalu di lakukan oleh kepala badan kesatuan dan politik Sulawesi Selatan untuk mendukung kinerja pegawai secara individu dalam pengembagan potensi masing-masing pegawai.

Pengaruh Kompetensi (X3) terhadap Kinerja (Y)

Data penelitian dengan perhitungan menggunakan program SPSS22.0for windows diperoleh nilai signifikan $0,032<\alpha=0,05$ menunjukkan bahwa Kompetensi berpengaruh terhadap Kinerja pada Lingkup Badan Kesatuan Bangsa dan Politik Provinsi Sulawesi Selatan. Berdasarkan hasil analisis dapat diketahui bahwa Kompetensitidak berpengaruh terhadap Kinerja pada Lingkup Badan Kesatuan Bangsadan Politik Propinsi Sulawesi Selatan.

Pengaruh Kompetensi Terhadap Kinerja Berdasarkan hasil analisis yang telah dilakukan menunjukkan terdapat pengaruh positif dan signifikan kompetensi terhadap kinerja pegawai Badan Kesatuan Bangsa dan Politik Sulawesi Selatan. Hasil penelitian ini mendukung penelitian yang dilakukan oleh Anwar (2001) dan Arlini (2010) bahwa kompetensi berpengaruh secara positif dan signifikan terhadap Kinerja. Sedangkan Jackson \& Mathis (2009) menyatakan bahwa kinerja dipengaruhi oleh kemampuan individu, tingkat usaha dan dukungan organisasi. Kemampuan individu dalam melakukan pekerjaan seperti bakat, minat dan faktor kepribadian individu. Tingkat usaha meliputi adanya motivasi, etika kerja, kehadiran dan rancangan tugas. Kemudian pelatihan dan pengembangan, peralatan dan teknologi, standar kerja, manajemen dan rekan kerja merupakan dukungan organisasi. Kompetensi merupakan karakteristik yang mendasar yang dimiliki seseorang yang berpengaruh langsung terhadap atau dapat memprediksi kinerja yang baik (Sedarmayanti , 2010).

Implikasinya bahwa untuk mencapai kinerja yang efektif dan efisien diperlukan adanya kemampuan individu meliputi tingkat usaha dan dukungan organisasi. Kemampuan pegawai Badan Kesbangpol Sulawesi Selatan dalam berkomunikasi, mengolah data dan berkoordinasi sangat mempengaruhi kinerja pegawai Badan Kesbangpol Sulawesi Selatan. Dengan kompetensi yang tinggi mampu meningkatkan kinerja pegawai Badan Kesbangpol Sulawesi Selatan dalam mencapai tujuan yang telah ditetapkan. Temuan peneliti dalam peningkatan kinerja kompensasi sangat berpengaruh sebagai motivasi pegawai dalam berpotensi dalam mendukung kemampuan setiap individu pegawai yang ada di badan Kesbangpol Sulawesi Selatan.

\section{KESIMPULAN}

Hasil penelitian berkesimpulan bahwa terdapat pengaruh positif dan signifikan lingkungan kinerja, motivasi dan kompetensi terhadap kinerja pegawai pada Badan Kesbangpol Provinsi Sulawesi Selatan. Upaya meningkatkan kinerja pegawai, pimpinan kantor Badan Kesbangpol Provinsi Sulawesi Selatan sebaiknya mampu menerapkan berbagai kebijakan tentang lingkungan kerja, motivasi dan kompetensi upaya yang dapat dilakukan misalnya dengan memberikan dorongan kepada pegawai dalam mengingkatkan kualitas dan kuantitas hasil kerja melalui pemberian reward dan tunjangan yang lebih baik serta menciptakan lingkungan kerja yang lebih baik sehingga pegawai dapat lebih meningkatkan kinerja dengan baik.

\section{DAFTAR PUSTAKA}

Amat Komari. (2001). "Marketing Pada Olahraga Badminton". Makalah Seminar Pemasaran. Yogyakarta: UGM

A.A. Anwar Prabu Mangkunegara. (2001), Manajemen sumber daya manusia perusahaan, Bandung: Remaja Rosdakarya. 
Arlini, Yuni. 2010. Pengaruh Motivasi dan Kompetensi Terhadap Kinerja Pegawai Biro Keuangan Sekretaris Daerah Pemerintah Provinsi Jawa Timur. Tesis. Diakses melalui http://www. eprints.upnjatim.ac.id

Cahyono, Budhi dan Suharto, 2005, pengaruh Budaya Organisasi, Kepemimpinan dan Motivasi Kerja Terhadap Kinerja Sumber Daya Manusia Di Sekretariat DPRD Propinsi Jawa Tengah, jurnal, JRBI Vol. 1, Yogyakarta

Donni Juni Priansa. 2017. Manajemen Pelayanan Prima. Albeta.

Gatot. 2014. Pengaruh Kompetensi, Disiplin Kerja, Pendidikan dan Pelatihan, Pola Karir terhadap Kinerja Pegawai Kantor Pertanahan Kabupaten Gunungkidul. Tesis Tidak Diterbitkan. Yogyakarta: UPN Veteran.Bandung.

Gibson, James L et al. 2006. Organizations (Behavior, Structure, Processes). Twelfth Edition, McGrow Hill.

Lewa, K., Iip, Idham, Eka dan Subowo, 2005, "Pengaruh Kepemimpinan, Lingkungan Kerja Fisik dan Kompensasi Terhadap Kinerja Karyawan di PT. Pertamina (Persero) Daerah Operasi Hulu Jawa Bagian Barat Cirebon." Jurnal SINERGI:Kajian Bisnis dan Manajemen Edisi Khusus on Human Resources.

Mathis, Robert L. \& Jackson. John H. (2009). Manajemen Sumber Daya Manusia. Jakarta: Penerbit Salemba Empat.

Nur, M., Nurkaidah, N., \& Nonci, N. (2020). Gaya Kepemimpinan Dan Sumber Daya Manusia Terhadap Kinerja Pegawai Pada Kantor Sekretariat Daerah Kabupaten MajenE. Jurnal Paradigma Administrasi Negara, 2(1), 24-31.

Puspita, RD. 2011. "Pengaruh Motivasi, Kompetensi, Kepemimpinan dan Lingkungan Kerja pada Kinerja Aparatur Penyuluh Keluarga Berencana.” Jurnal Ilmu Administrasi Negara, Volume 11 (1), pp. $87-96$

Sedarmayanti. 2010. Manajemen Sumber Daya Manusia Reformasi Birokrasi dan Manajemen Pegawai Negeri Sipil. Alfabeta. Bandung.

Sugiyono. 2017. Metode Penelitian Kuantitatif, Kualitatif dan R\&D. Alfabeta, Bandung.

Sutrisno, Edi. 2009. Manajemen Sumber Daya Manusia Edisi pertama. Jakarta: Kencana Prenada Media Group.

Wibowo. 2009. Manajemen Kerja. Jakarta: PT. Raja Grafindo Persada. 